\title{
Comparison of Anammox Treatment Performances Using Different Kinds of Biomass Carriers
}

\author{
SEN QIAO ${ }^{1}$, KOHEI HATA ${ }^{1}$, YINGJUN CHENG ${ }^{1}$, YASUHIKO INATOMI ${ }^{1}$, \\ TAKASHI NISHIYAMA ${ }^{2}$, TAKAO FUJII' ${ }^{2}$ TOICHIRO KOYAMA ${ }^{3}$, and KENJI FURUKAWA ${ }^{1}$ \\ ${ }^{1}$ Graduate School of Science and Technology, Kumamoto University \\ /Kurokami 2-39-1, Kumamoto, 860-8555 Japan \\ ${ }^{2}$ Department of Applied Life Science, Faculty of Biotechnology and Life Science, Sojo Univeristy \\ /Ikeda 4-22-1, Kumamoto, 860-0082 Japan \\ ${ }^{3}$ NET Co. Ltd./Kohyohdai 3-6-216, Kawanishi, Hyogo, 666-0115, Japan
}

\begin{abstract}
The anammox process, as an alternative to conventional nitrogen removal technologies, has abstracted much attention in recent years. In this study, two column-type reactors using different support materials-net type acrylic fiber (Biofix) and polyester nonwoven-were used for anammox treatment. The nonwoven reactor was operated at $35^{\circ} \mathrm{C}$ and the Biofix reactor at $25^{\circ} \mathrm{C}$ (peak summer temperature, $31.5^{\circ} \mathrm{C}$ ). Over 330 days of operation, the nitrogen loading rates of the Biofix and nonwoven reactors were increased to $3.6 \mathrm{~kg}-\mathrm{N} / \mathrm{m}^{3} / \mathrm{d}$ and $4.0 \mathrm{~kg}-\mathrm{N} / \mathrm{m}^{3} / \mathrm{d}$ and $\mathrm{T}-\mathrm{N}$ removal efficiencies reached to $81.3 \%$ and $86.3 \%$, respectively. A protein substance was shown to be the most abundant extracellular polymeric substances (EPS) in the anammox sludge with almost three times more in the granular sludge of the Biofix reactor than in the granular sludge of the nonwoven reactor. Considering the EPS levels and observation by scanning electron microscopy, the anammox granules in the Biofix reactor were denser than that in the nonwoven reactor. Results of DNA analyses indicated that the KSU-1 strain might prefer relatively low nutrient levels, while the KU2 strain might be better suited for the high media concentration. Other kinds of bacteria were also identified with the potentials for consuming the dissolved oxygen in the influent and facilitating anammox bacteria surviving under aerobic conditions.
\end{abstract}

Key words: Anammox, nitrogen removal, EPS, DNA analysis

\section{INTRODUCTION}

Anammox, as a potentially useful autotrophic biological processes, was discovered about 14 years ago ${ }^{1,2)}$. In this process, nitrite serves as an electron acceptor, combining with ammonium to produce dinitrogen gas, the only environmentally friendly form of nitrogen. The species responsible for this nitrogen conversion has been identified as a deeply branching planctomycete with a doubling time of 11 days $^{3)}$. The stoichiometry of the anammox reaction was determined by Strous et $a l^{4)}$ to be:

$$
\begin{aligned}
& \mathrm{NH}_{4}{ }^{+}+1.32 \mathrm{NO}_{2}{ }^{-}+0.066 \mathrm{HCO}_{3}{ }^{-}+0.13 \mathrm{H}^{+} \rightarrow \\
& 1.02 \mathrm{~N}_{2}+0.26 \mathrm{NO}_{3}{ }^{-}+0.066 \mathrm{CH}_{2} \mathrm{O}_{0.5} \mathrm{~N}_{0.15}{ }^{+} \\
& 2.03 \mathrm{H}_{2} \mathrm{O}
\end{aligned}
$$

Biofilm reactors have been applied for anammox research, such as fixed bed, fluidized bed and gas lift reactors ${ }^{5,6,7,8)}$. In order to improve the retention of anammox biomass, the SBR reactor has also been applied for anammox sludge cultivation; 
however, mechanical stirring could not adequately provide solid-gas separation and the sludge floating became a serious problem, which resulted in deterioration of effluent quality $^{6,8,9)}$. In our laboratory, a nonwoven biomass carrier was successfully used for cultivation of the slowly growing anammox microorganisms ${ }^{10)}$. Trigo et al. used a membrane sequencing batch reactor for anammox research and demonstrated that this kind of membrane reactor could be suitable for nitrogen removal ${ }^{11)}$.

Although these kinds of biofilm systems could obtain good performances during anammox laboratory studies, it was inevitable that valuable biomass would washout from the reactors. In this study, two up-flow column-type reactors, one with the nonwoven carrier and the other with the Biofix carrier, were applied for anammox research at the operational temperature of $35^{\circ} \mathrm{C}$ and $25^{\circ} \mathrm{C}$ (in summer season the temperature of Biofix reactor was over $25^{\circ} \mathrm{C}$ ), respectively. The nonwoven material used here has demonstrated effectiveness in retention of biomass in unit processes designed for nitrification, nitrophenol degradation, and anammox ${ }^{10,12,13)}$. Although the Biofix material is applied here for the first time in an anammox study, it has shown to have potential for single-stage nitrogen removal by combining anammox and partial nitrification (SNAP) process ${ }^{14)}$. The

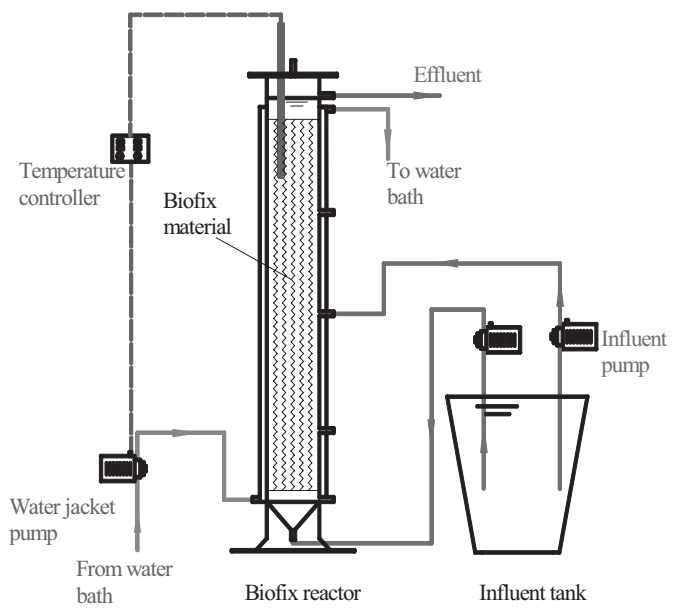

(a) Biofix reactor anammox treatment performances of two systems were compared under various operational and temperature conditions. Extracellular polymeric substances (EPS) and scanning electron microscopy (SEM) of anammox biomass were also utilized for characterization of the microorganisms. In addition, 16S rDNA analyses were applied for determining the species of the microorganism in the reactors.

\section{MATERIALS AND METHODS}

Biofix experiment set-up An up-flow column type reactor was used for the anammox study including Biofix as the support material as shown in Fig. 1. The reactor had a square $\left(15^{-} \mathrm{cm}\right.$ by $\left.15^{-} \mathrm{cm}\right)$ cross section and height (to effluent port) of 102 $\mathrm{cm}$. The reaction zone, including influent distribution and biomass retention sections, was $18.8 l$. The Biofix biomass carrier was made of acrylic resin with a specific surface area of $113.8 \mathrm{~m}^{2} / \mathrm{m}^{3}$. Five bundles of the Biofix material were inserted in the reactor for a volume of $4.24 l\left(22.6 \%\right.$ pack, $25.5 \mathrm{~m}^{2} /$ $\mathrm{m}^{3}$-reactor). The system was usually operated at $25^{\circ} \mathrm{C}$, controlled thermostatically in a water bath, and the thermostat heater was not used in summer season due to the room temperature being continuously in excess of $25^{\circ} \mathrm{C}$ (peak $31.5^{\circ} \mathrm{C}$ ). In addition, dark conditions were maintained with a black-

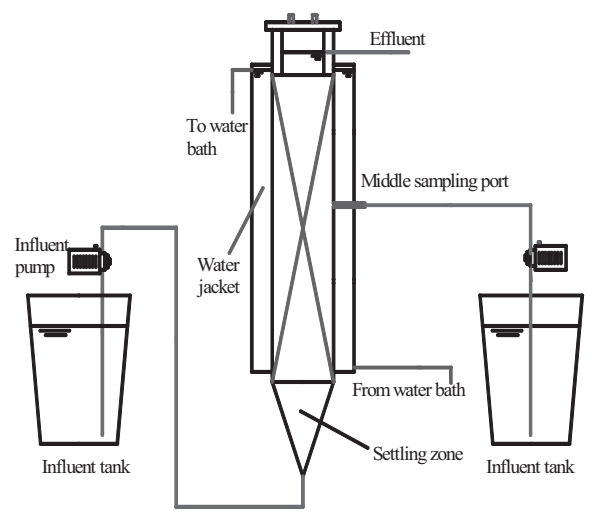

(b) nonwoven reactor

Fig. 1 Schematic diagram of Biofix and nonwoven reactors 
vinyl sheet enclosure.

Nonwoven experiment set-up The anammox reactor utilizing the nonwoven material was made by acrylic resin. The reactor had an inner diameter of $24.0 \mathrm{~cm}$ and height (to effluent port) of $112 \mathrm{~cm}$. The liquid volume was $50.7 l$ and the reaction zone was $54.3 l$. The reactor was capped and fitted with an effluent trap. The nonwoven carrier was a porous polyester material $(100 \times 2 \mathrm{~cm}$ strips, $1.0 \mathrm{~cm}$ thickness) coated with a pyridinium type polymer (US patent, 5185415; Japan Vilene Co., Ltd.) designed to enhance retention of microorganisms. In the reaction zone, there were 36 vertically suspended nonwoven strips for a total-one sided sheet area of $0.72 \mathrm{~m}^{2}\left(14.2 \mathrm{~m}^{2} / \mathrm{m}^{3}\right.$-reactor $)$. The reactor was operated at $35^{\circ} \mathrm{C}$, thermostatically controlled by water jacket. In addition, dark conditions were maintained with a blackvinyl sheet enclosures.

Inocula The Biofix reactor was inoc-

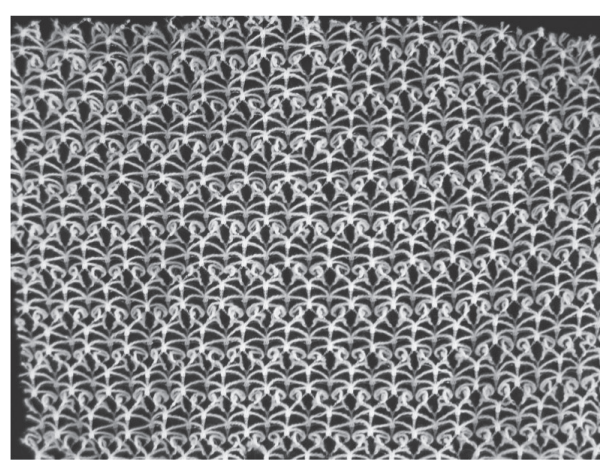

(a) Biofix

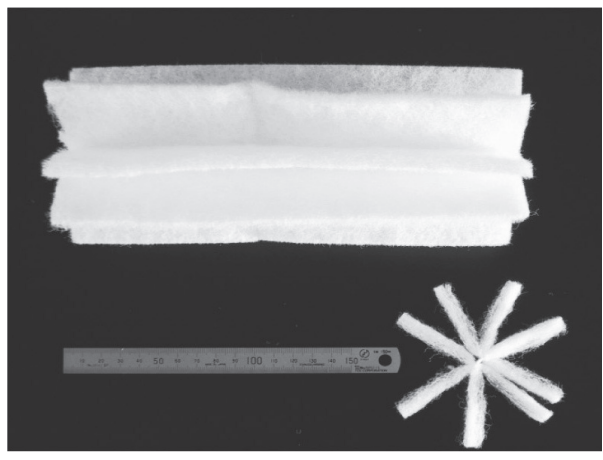

(b) Nonwoven

Fig. 2 Photos of Biofix and nonwoven materials ulated from another laboratory scale fix-bed anammox reactor operated at the Kumamoto University ${ }^{12}$. The initial MLVSS concentration for the Biofix reactor was $1,706 \mathrm{mg} / l$. The nonwoven reactor was also inoculated from the same anammox reactor with an initial MLVSS concentration of $1,034 \mathrm{mg} / l$.

Operational conditions of reactors For the two reactors, both increment of influent ammonium and nitrite concentrations and decrease in hydraulic retention time (HRT) were alternatively applied for increasing the nitrogen loading rate (NLR). Increase in NLR was performed after the limiting substrate nitrite removal efficiency of $80 \%$ or greater was obtained.

Feeding media Both reactors were fed with synthetic media, with $\left(\mathrm{NH}_{4}\right)_{2} \mathrm{SO}_{4}$ and $\mathrm{NaNO}_{2}$ serving as influent ammonium and nitrite, respectively. $\mathrm{KHCO}_{3}, \mathrm{KH}_{2} \mathrm{PO}_{4}, \mathrm{FeSO}_{4}$ • $7 \mathrm{H}_{2} \mathrm{O}$ and EDTA $\cdot 2 \mathrm{Na}$ were also added as shown in Table 1.

Analytical methods $\mathrm{NO}_{3}-\mathrm{N}$ was measured by quantified by using the UV spectrophotometric screening method and $\mathrm{NO}_{2}-\mathrm{N}$ by the colorimetric method ${ }^{15}$. $\mathrm{NH}_{4}-\mathrm{N}$ was quantified by the method described by Kanda using involving the use of o-phenylphenol as a substitute for liquid phenol ${ }^{16)}$. DO was measured using a DO meter (HORIBA, $\mathrm{pH} /$ DO meter $\mathrm{D}^{-55}$ ).

For EPS measuring, proteins were measured using the method of Lowry et al. ${ }^{17)}$ and carbohydrates by the method of Dubois et al. ${ }^{18)}$. Nucleic acids (combined RNA and DNA) were estimated by the UV absorption method $^{19)}$ using the following equation:

$$
\begin{aligned}
& \text { Nucleic acids }(\mathrm{g} / l) \\
& =30.98 A /(10000 \cdot(0.09) b)
\end{aligned}
$$

\begin{tabular}{|c|c|c|}
\hline \multirow{2}{*}{ Compound } & \multicolumn{2}{|c|}{ Concentration $(\mathrm{mg} / \mathrm{l})$} \\
\hline & Biofix reactor & Nonwoven reactor \\
\hline$\left(\mathrm{NH}_{4}\right)_{2} \mathrm{SO}_{4}$ & $50-300$ & $30-330$ \\
\hline $\mathrm{NaNO}_{2}$ & $50-300$ & $30-330$ \\
\hline $\mathrm{KHCO}_{3}$ & 125 & 125 \\
\hline $\mathrm{KH}_{2} \mathrm{PO}_{4}$ & 54 & 54 \\
\hline $\mathrm{FeSO}_{4} \cdot 7 \mathrm{H}_{2} \mathrm{O}$ & 9 & 9 \\
\hline $\mathrm{EDTA} \cdot 2 \mathrm{Na}$ & 5 & 5 \\
\hline
\end{tabular}

Table 1 Composition of synthetic medium 
where, 30.98 is the gram molecular weight of phosphorous, $A$ is the absorbance of the sample solution at $260 \mathrm{~nm}, 10,000$ is the constant of proportionality (absorbtivity) of phosphorous in nucleic-acid form (average of the RNA and DNA components), 0.09 is the weight fraction of phosphorous in nucleic acids and $b$ is the absorbance light path (1.0 $\mathrm{cm}$ in this study).

For SEM, samples were first washed in a $0.1 \mathrm{M}$ phosphate buffer solution $(\mathrm{pH}$ 7.4) for 5 min each time. Then samples were hardened for $90 \mathrm{~min}$ in a $2.5 \%$ glutaraldehyde solution prepared with the buffer solution. Next, samples were washed in the buffer solution three times for $10 \mathrm{~min}$ and then fixed for 90 min in a $1.0 \% \mathrm{OsO}_{4}$ solution prepared with the buffer solution. After washing samples three times for $10 \mathrm{~min}$ each in the buffer solution, they were dewatered for $10 \mathrm{~min}$ each in serially graded solutions of ethanol at concentrations of $10,30,50,70,90$, and $95 \%$. SEM observations were conducted using a scanning electron microscope (JEOL, JSM5310LV).

The abundance of bacteria in the community of the sludge used was estimated from the image of denaturing gradient gel electrophoresis (DGGE). Metagenomic DNA was extracted from the sludge using ISOIL kit (Nippon gene Co., Ltd., Tokyo, Japan). Partial 16S rRNA genes in the metagenome were amplified by PCR with a primer set, $357 \mathrm{~F}$ with a GC-clamp and 534R $\mathrm{R}^{20}$. The amplified fragments were resolved by DGGE for $16 \mathrm{hr}$ at $100 \mathrm{~V}$ at $60^{\circ} \mathrm{C}$ using DCode system (Bio-Rad Laboratories, Hercules, CA, USA). An $8 \%$ acrylamide gel with a $30-$ to- $65 \%$ denaturing gradient was used, where $100 \%$ denaturant was defined as $7 \mathrm{M}$ urea and $40 \%$ formamide. The gel was stained with SYBR-Gold solution (Invitrogen Corp., Carlsbad, CA, USA), and visualized as a 16-bit gray-scale image using FLA-2000 system (Fuji Photo Film Co., Ltd., Tokyo, Japan). The intensities of all bands were quantified using a software, Image Gauge v3.4, included in the system. KSU-1 population content was calculated from the corresponding band intensity and the sum of all band intensities ${ }^{20)}$.

\section{RESULTS AND DISCUSSION}

Biofix reactor Operation was continued about 330 days without interruption. The NLRs were increased from 0.05 to $3.6 \mathrm{~kg}-\mathrm{N} /$ $\mathrm{m}^{3} / \mathrm{d}$ by means of increasing the concentrations of nitrogen compounds $\left(\mathrm{NH}_{4}{ }^{+}\right.$and $\left.\mathrm{NO}_{2}^{-}\right)$and shortening the HRT as shown in Fig. 3. In the first phase, NLRs were increased by

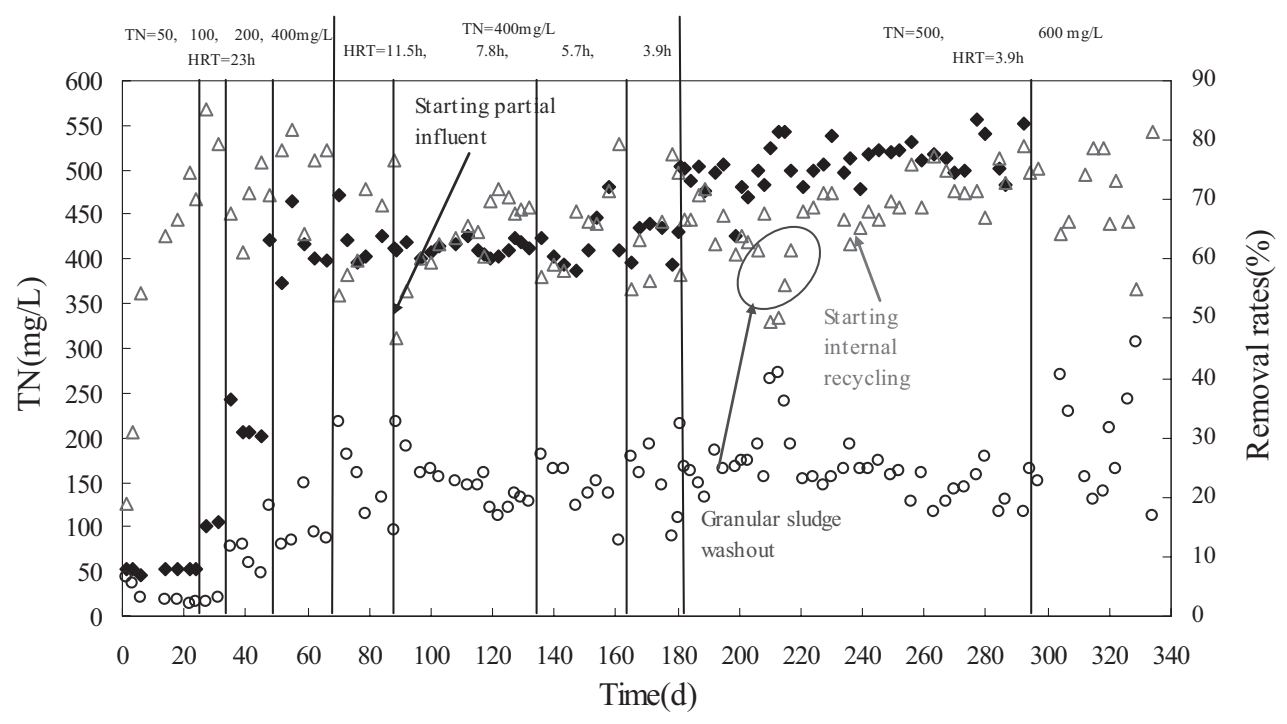

Fig. 3 Time courses of TN concentration and removal rates Influent $\bigcirc$ Effluent $\triangle$ Removal rate 
increasing influent $\mathrm{T}-\mathrm{N}$ concentrations stepwise at a constant HRT of $23 \mathrm{~h}$. Because the reactor was initially at an ambient temperature of about $25^{\circ} \mathrm{C}$, the anammox biomass could not adapt well and had very low activities. It took 24 days for the $\mathrm{T}-\mathrm{N}$ removal efficiency to progress from $19 \%$ to $78 \%$. Subsequently, stable anammox activities were maintained and average $\mathrm{T}-\mathrm{N}$ removal rates of $75 \%$ was observed even the influent $\mathrm{T}-\mathrm{N}$ concentration was increased to $400 \mathrm{mg} / \mathrm{l}$ (NLR of $0.4 \mathrm{~kg}-\mathrm{TN} / \mathrm{m}^{3} / \mathrm{d}$ ). Moreover, the removal efficiencies did not drop sharply even when the T-N level was doubled. It was concluded that increasing the NLRs by increasing the influent $\mathrm{T}-\mathrm{N}$ concentration was not harmful to anammox treatment performance. In phase II, TN levels were kept stable and HRT was shortened to increase the NLRs over about 120 days operation. In the end, the NLR was increased to $2.5 \mathrm{~kg}-\mathrm{TN} / \mathrm{m}^{3} / \mathrm{d}$ and the highest $\mathrm{T}-\mathrm{N}$ removal of $77 \%$ was achieved. Compared with phase I, changing the NLR by shortening the HRT resulted in more harmful influences on anammox treatment performance. For example, when the HRT was shortened from $11.5 \mathrm{~h}$ to $7.8 \mathrm{~h}$ and from 5.7 to $3.9 \mathrm{~h}, \mathrm{~T}-\mathrm{N}$ removal efficiencies decreased by $31 \%$ and
$25 \%$, respectively.

A relatively high influent $\mathrm{T}-\mathrm{N}$ of $500 \mathrm{mg} / \mathrm{l}$ was associated with unstable nitrogen removal performances. $\mathrm{N}$ removal efficiencies were diminished owing to the washout of granular sludge, formed by the detached anammox sludge, from day 210 to day 220 . Internal recycling was applied to mitigate the problem on day 238. During this period, the highest T-N removal efficiency of $81.3 \%$ was achieved at a NLR of $3.6 \mathrm{~kg}-\mathrm{N} / \mathrm{m}^{3} / \mathrm{d}(\mathrm{TN}$ of $600 \mathrm{mg} / l$, HRT of $3.9 \mathrm{~h}$ ). In Fig. 4 , TN removal, nitrite removal and nitrate production rates are shown, which are in good agreement with the stoichiometric equation of the anammox reaction (Eq. (1)). Though the results are described on a mass concentration basis, conversion to a mole basis would yield the same results.

Nonwoven reactor For the nonwoven reactor, NLRs were increased by the combination of increasing the influent $\mathrm{T}-\mathrm{N}$ concentrations and shortening the HRT. Fig. 5 shows the changes in $\mathrm{T}-\mathrm{N}$ loading and removal rates for the nonwoven reactor. In the first 2 weeks, T-N levels were increased from about $50 \mathrm{mg} / l$ to $100 \mathrm{mg} / \mathrm{l}$ at a HRT of $15 \mathrm{~h}$, but only about $60 \%$ removal rates were achieved. On day 40, the removal rates

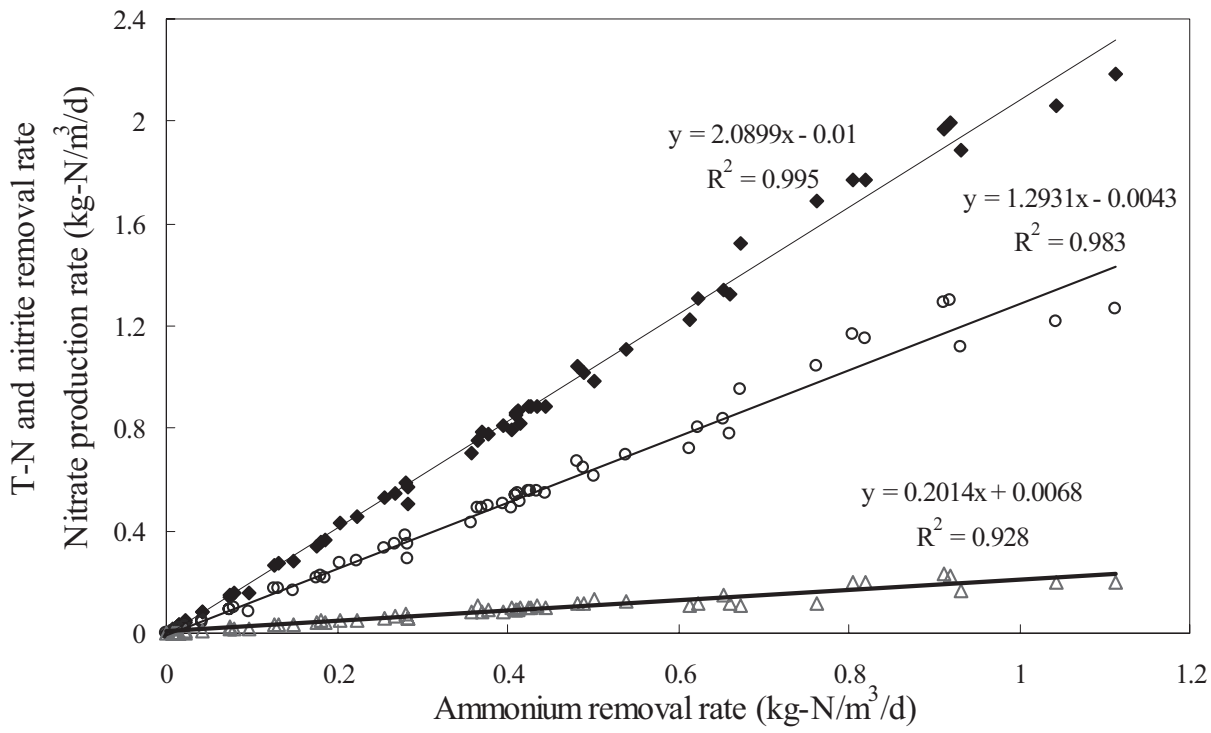

Fig. 4 Relationship between ammonium removal rate, $\mathrm{T}-\mathrm{N}$ removal rate, nitrite removal rate and nitrate production rate $\checkmark \mathrm{T}-\mathrm{N} \bigcirc$ Nitrite $\triangle$ Nitrate 

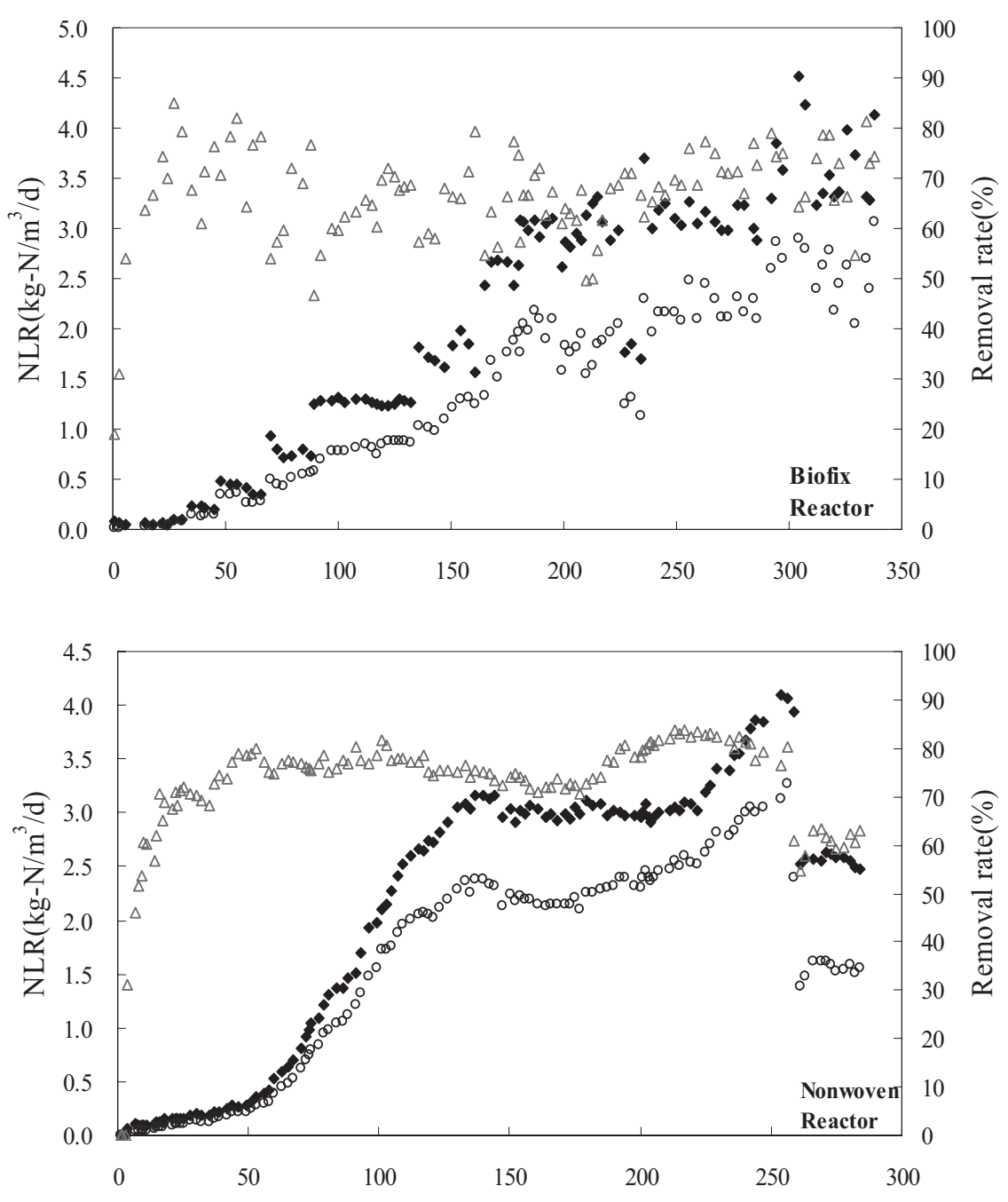

Time(d)

Fig. 5 Comparison of removal performances for Biofix and nonwoven reactor - Influent $\bigcirc$ Eflluent $\triangle$ Removal rate

increased by over $70 \%$ when influent $\mathrm{T}-\mathrm{N}$ reached $270 \mathrm{mg} / \mathrm{l}$ at a HRT of $15 \mathrm{~h}$. During the following 220 days, the nonwoven reactor always maintained high removal rates even with NLRs of up to $4.0 \mathrm{~kg}-\mathrm{N} / \mathrm{m}^{3} / \mathrm{d}$. However, long time operations under high nitrogen loading and high influent nitrite concentrations had taken a harmful effect to the anammox biomass in the nonwoven reactor. On day 259 , the high strength made the $\mathrm{T}-\mathrm{N}$ removal efficiency suddenly decreased to $60.7 \%$ and found that it was difficult to recover the system removal performances in a short time even reducing the NLRs to a relative low level.

Comparing with the Biofix reactor, the nonwoven reactor demonstrated a shorter startup time and greater treatment stability under a relatively high loading. For the nonwoven reactor, startup was completed successfully within 2-3 weeks and NLRs could increase to $3.0 \mathrm{~kg}-\mathrm{N} / \mathrm{m}^{3} / \mathrm{d}$ within 4 months of operation with $\mathrm{T}-\mathrm{N}$ removal rates of about $75 \%$. The relative high operation at 
temperature may mainly benefit for the satisfactory performance of nonwoven reactor, and the high total anammox biomass in nonwoven reactor (52.4 g-TSS) stabilized the removal performance comparing with Biofix reactor. Moreover, the method of simultaneous increasing in nitrogen concentration and shortening HRT for nonwoven reactor demonstrated to be a better treatment performance than that obtained for Biofix reactor. When the NLR reached $4.0 \mathrm{~kg}-\mathrm{N} /$ $\mathrm{m}^{3} / \mathrm{d}$ (TN of $650 \mathrm{mg} / l$, HRT of $2 \mathrm{~h}$ ), a high T-N removal rate of $80.2 \%$ was observed.

EPS EPS assists in the formation of microbial aggregates whether the biomass is in suspended or biofilm states. EPS is thought to support the metabolic cooperation among cells in aggregate form. Moreover, it benefits surface adhesion, cell aggregation in flocs and biofilms, stabilization of biofilm structure, etc $^{21}$. Fig. 6 shows a comparison of EPS levels in anammox granular sludge and attached biomass of the Biofix reactor. From this figure, it is clear that protein was the predominated component in the EPS of anammox sludge. Furthermore, EPS levels for granular sludge were almost two times higher than those of attached biomass, which suggests that high EPS levels would be beneficial for the formation of granular sludge.

Previously, most researchers reported that polysaccharide was the most abundant component EPS fraction ${ }^{22)}$. However, protein and nucleic acid are also significant components in EPS and possibly the largest fraction. Nielsen et al. and Dignac et al. quantified the EPS composition of activated sludge in different wastewater treatment systems, and found that protein was dominate $^{23,24)}$. Laspidou and Rittmann considered that due to the high content of negatively charged amino acids, protein was more involved than sugars in electrostatic bonds with multivalent cations, a key factor in stabilizing aggregate structure ${ }^{25}$. The other significant function of extracellular protein is as enzymes performing the digestion of macromolecules and particulate material in the microenvironment of embedded cells, which could trap, bind, and concentrate organic materials in close proximity to the cells ${ }^{25)}$. Extracellular enzymes are also localized near the cells and could hydrolyze the adsorbed organic materials. Wingender and Hoffman considered that the proximity of extracellular hydrolysis to the cells could favor efficient inception of low-formula hydrolysis products by reducing diffusion loss of products to the surrounding water ${ }^{21,26)}$. The EPS levels of granular sludge in the two reactors were also compared (Fig. 7). It was demonstrated that extracellular protein was the main fraction enabling the formation of granular sludge according to the above discussion. From this figure, it is evident that the EPS level of the granular sludge in the Biofix reactor was more than double that of the nonwoven reactor, which suggests that the granular sludge in the Biofix reactor would probably have a more compact structure.

SEM observation The SEM photos of

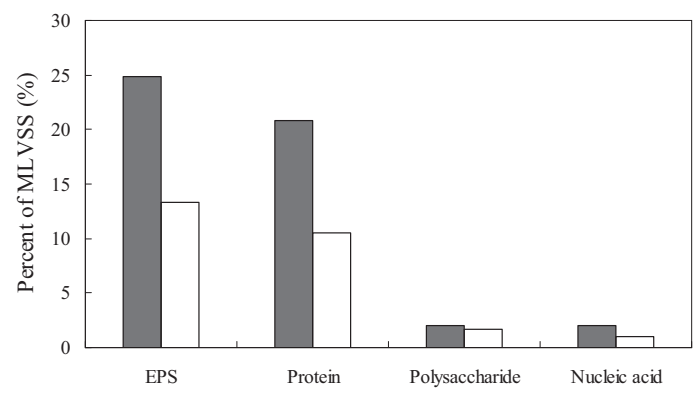

Fig. 6 EPS comparison of granular and attached biomass in Biofix reactor

$\square$ Granular sludge $\square$ Attached sludge

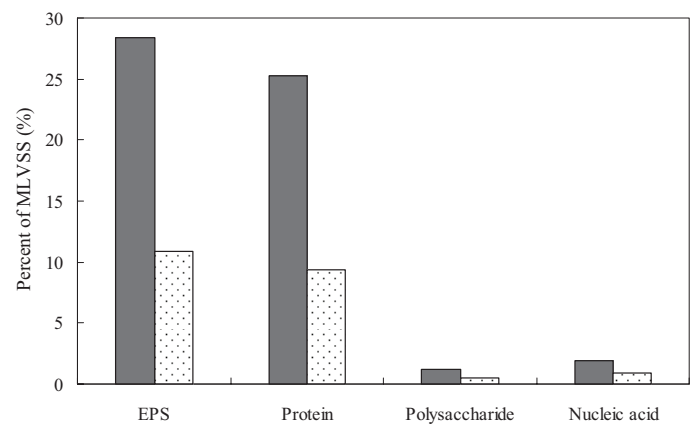

Fig. 7 EPS comparison of granular sludge in Biofix and nonwoven reactor

Biofix reactor $\therefore$ Nonwoven reactor 
the granular sludge in the Biofix reactor show a high degree of compactness (Fig. 8 (a)). Each micro-element was tightly integrated with other parts and there was little interspace between them. However, there existed a lot of branch-like microstructures on the surface of the granular sludge in the nonwoven reactor and the spaces between the micro units were larger than those of the Biofix reactor. Based on the SEM observation of the granular anammox sludge of two reactors, it was concluded that the micro-organization structure in the Biofix reactor presented higher compactness than those in nonwoven reactor. Fig. 9 shows the SEM photos of the attached biomass on Biofix materials. The micro-organization structure exhibited sphericity in the microcosmic point of view. This structure may be formed with the shear forces caused by the upward flow of gas bubbles and water currents in the spaces between support materials. The Biofix materials with its nettype structure provided a favorable environment for the attached biomass allowing for effective contact with nutrients, gas and water current.

DNA analysis Fig. 10 shows DGGE photos of the nonwoven and Biofix reactors operated at an NLR of $3.0 \mathrm{~kg}-\mathrm{N} / \mathrm{m}^{3} / \mathrm{d}$ to 3.2 $\mathrm{kg}-\mathrm{N} / \mathrm{m}^{3} / \mathrm{d}$. Samples were taken out of the reactors from the bottom, middle and upper parts and the granular sludge of the Biofix reactor was also investigated. For the nonwoven reactor, relative amounts of the anammox bacterium KSU-1 strain $^{27)}$ exhibited a decreasing tendency from top to bottom parts, e.g, there was about $20 \%$ in the upper and middle parts and only $15 \%$ in the bottom part; while the anammox bacterium KU2 strain $^{12)}$ showed the reverse trend. For the Biofix reactor, the KU2 strain was dominant

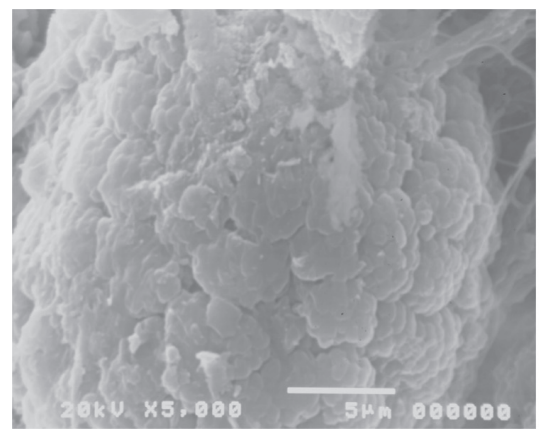

(a) BX

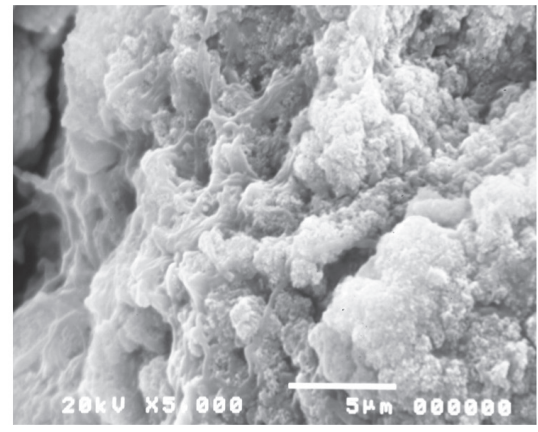

(b) Nonwoven

Fig. 8 Comparison of surface condition of granular sludge

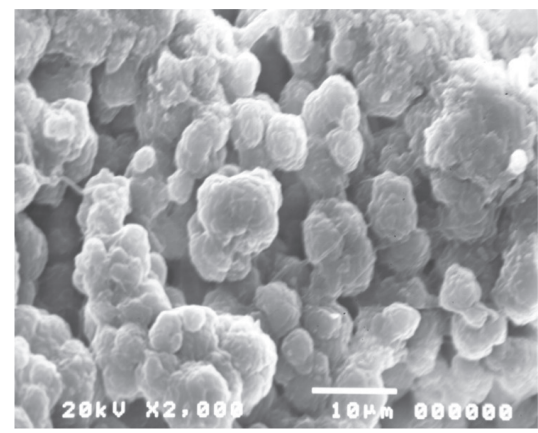

(a)

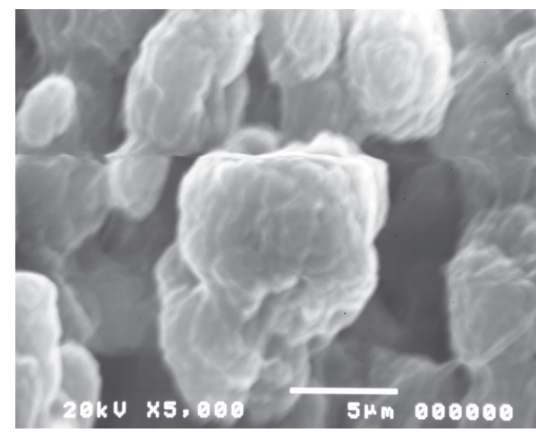

(b)

Fig. 9 SEM photos of attached biomass on Biofix 


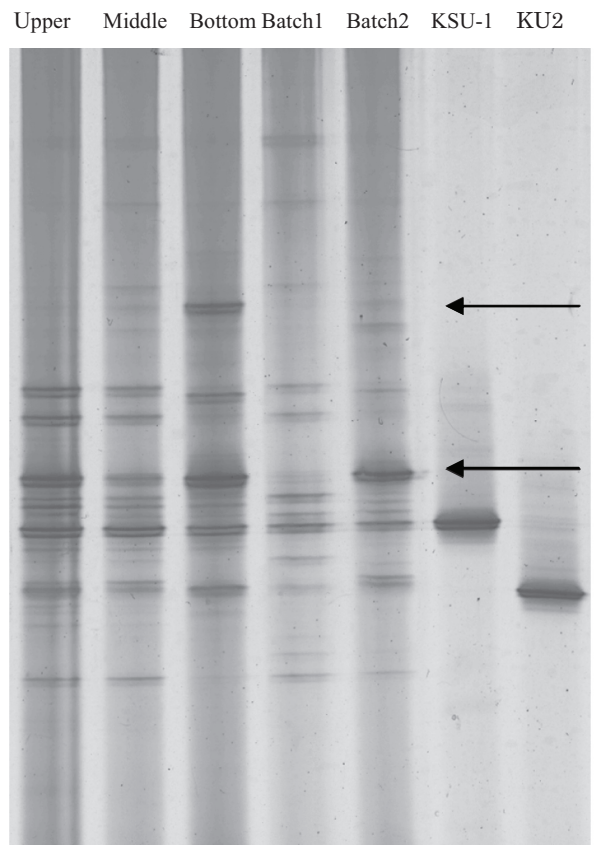

(a) nonwoven
KSU-1 KU2 Upper Middle Bottom Granular NB

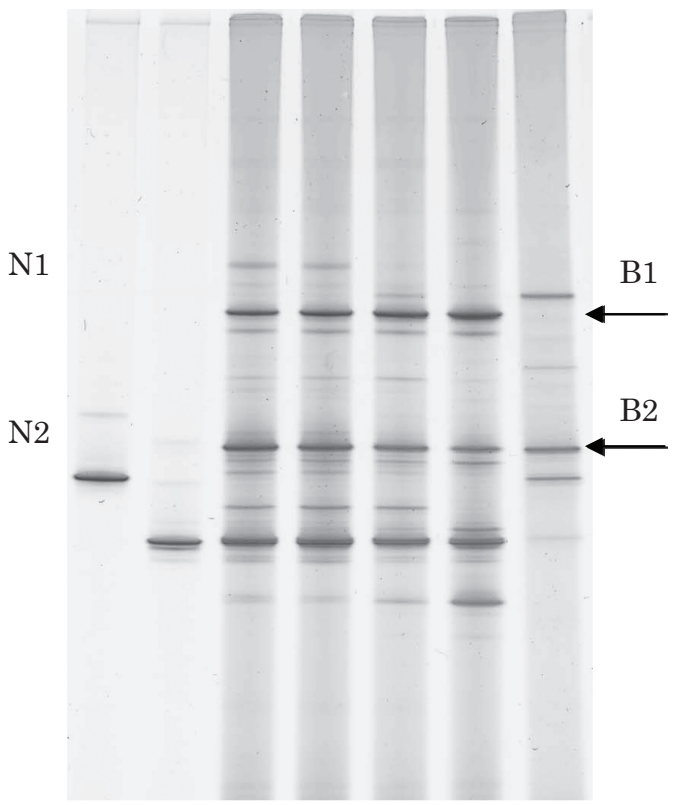

(b) Biofix

Fig. 10 DGGE results of different parts in Nonwoven and Biofix reactors

Note: Line Batch 1 and Batch 2 mean the samples were taken from the upper and bottom parts of Nonwoven reactor for batch experiment;

Line NB means the samples from bottom part of Nonwoven reactor just for comparing

and the four KU2 bands of the different parts demonstrated almost identical concentrations; while the KSU-1 concentrations in the Biofix reactor showed much lower levels relative to KU2; however, an increasing trend from the bottom upward of the KSU-1 strain could be distinguished based on the thickness of the bands.

Since bands N2 and B2 are at almost the same level, they were identified as Chloroflexi belonging to the green non-sulfur bacteria (AB113620, identity of $100 \%$; AB113606, identity of $100 \%)$. The Chloroflexi bacteria are facultative anaerobes frequently found in UASB reactors that are filamentous and often associated with sludge granulation and bulking. Recently this type of bacteria was also found in a methane fermentation process where it consumed the organic compounds in the reactor. Due to its anaerobic respiration metabolism, it was postulated that this bacteria could consume nitrite or nitrate.
Band N1 mainly distributed at the bottom with a high concentration. The sequence of the band was matched to two kinds of database entries, which had the same base pair array, uncultured bacterium clone K4_33 (AY793665) and uncultured bacterium PHOSHE36 (AF314435). The sources of these bacteria were lake sediment and an aerobic phosphorus-removal ecosystem, respectively. The sources of these bacteria with high matches to this band were of both anaerobic and aerobic conditions, thus band N1 was thought to be a facultative bacteria or one capable of metabolism under micro-aerobic conditions, enabling it to consume the DO in the influent. In addition, band $\mathrm{B} 1$ was identified as a close match to the uncultured bacterium PHOS-HE36 (identity of 97\%, accession: AF314435). This type of bacteria could also consume the DO in the influent and survive under the anaerobic and anoxic conditions. 


\section{CONCLUSIONS}

Two column-type upflow anammox reactors with different carrier materials showed high nitrogen removal performances. In a Biofix reactor, a TN removal efficiency of $81.3 \%$ was observed with a NLR of $3.6 \mathrm{~kg}-\mathrm{N} / \mathrm{m}^{3} / \mathrm{d}$ at a temperature of $25^{\circ} \mathrm{C}$, while for a nonwoven reactor, a high $\mathrm{TN}$ removal efficiency of $86.3 \%$ was obtained even with a NLR of 4.0 $\mathrm{kg}-\mathrm{N} / \mathrm{m}^{3} / \mathrm{d}$. Comparing the levels of EPS in the anammox granular sludge in two reactors, it was found that protein was the dominant fraction and the EPS content of anammox granular sludge in the Biofix reactor was almost three times higher than that in the nonwoven reactor (28.4\% versus $10.9 \%)$. Based on the analysis of EPS and SEM observation, the anammox granular sludge in the Biofix reactor was revealed to have a more compact state than that in the nonwoven reactor. The microstructure of anammox sludge attached on the Biofix material exhibited a spherical form in SEM photos, which may be due to shear forces caused by the upward flow of gas bubbles and water through the support materials. DNA analyses revealed four unknown sequences. Two DNA bands were identified as Chloroflexi belonging to the green non-sulfur bacteria, which have the function of consuming nitrite or nitrate in the reactor. One of these bands was matched to two database entries of the uncultured bacterium clone K4_33 (AY793665) and the uncultured bacterium PHOS-HE36 (AF314435). The other band was identified as a close match to the uncultured bacterium PHOS-HE36 (identity of 97\%, accession: AF314435). All these bacteria can serve the function of consuming DO in the influent, thereby potentially assisting the anammox microorganism to function under macroaerobic conditions.

\section{REFERENCES}

1 ) Mulder A., van de Graaf A.A., Robertson L.A., and Kuenen J.G.: Anaerobic ammonium oxidation discovered in a denitrifying fluidized bed reactor. FEMS Microbiol. Ecol., 16, 177-184 (1995)

2 ) Van de Graaf A.A., Mulder A., de Bruijn P.,
Jetten M.S.M., Robertson L.A., and Kuenen J.G.: Anaerobic oxidation of ammonium is a biologically mediated process. Appl. Environ. Microbiol., 61, 1246-1251 (1995)

3 ) Strous M., Fuerst J.A., Kramer E.H.M., Logemann S., Muyzer G., van de Passchoonen K.T., Webb R., Kuenen J.G., and Jetten M.S.M.: Missing lithotroph identified as new planctomycete. Nature, 400, 446-449 (1999)

4 ) Strous M., Heijnen J.J., Kuenen J.G., and Jetten M.S.M.: The sequentcing batch reactor as a powerful tool for the study of slowly growing anaerobic ammoniumoxidizing microorganism. Appl. Microbiol. Biotechnol., 50, 589-596 (1998)

5 ) Van de Graaf A.A., de Bruijn P., Robertson L.A., Jetten M.S.M., and Kuenen J.G.: Autotrophic growth of anaerobic ammonium-oxidezing microofganisms in a fluidized bed reactor. Appl. Environ. Microbiol., 142, 2187-2196 (1996)

6 ) Strous M., van Gerven E., Kuenen J.G., and Jetten M.: Ammonium removal from concentrated wate steams with the anaerobic ammonium oxidation (Anammox) process in different reactor configurations. Water Res., 31, 1955-1962 (1997)

7 ) Sliekers A.O., Third k., Abma W., Kuenen J.G., and Jetten M.S.M.: Canon and Anammox in a gas-lift reactor. FEMS Microbiol. Lett., 218, 339-344 (2003)

8 ) Depena-Mora A., Campos J.L., MosqueraCorral a., Jetten M.S.M., and Mendez R.: Stability of annmox process in a gas-lift reactor and a SBR. J. Biotechnol., 110, 159-170 (2004)

9 ) Strous M., Kuenen J.G., and Jetten M.S.M.: Key physiological parameters of anaerobic ammonium oxidation. Appl. Microbiol. Biotechnol., 65, 3248-3250 (1999)

10) Furukawa K., Rouse J.D., Yoshida N., and Hatanaka H.: Mass cultivation of anaerobic ammonium-oxidizing sludge using a novel nonwoven biomass carrier. J. Chem. Eng. Jpa., 36(10), 1163-1169 (2003)

11) Trigo C., Campos J.L., Carrido J.M., and Mendez R.: Start-up of the anammox process in a membrane bioreactor. J. Biotechnol., 126 (4), 475-487 (2006)

12) Furukawa K., Rouse J.D., Imajo U., Nakamura K., and Ishida H.: Anaerobic oxidation of 
ammonium confirmed in continuous flow treatment using a non-woven biomass carrier. Japanese Journal of Water Treatment Biology, 38 (2), 87-94 (2002)

13) Bhatti Z.I., Toda H., and Furukawa K.: p-Nitrogenphenol degradation by activated sludge attached on nonwovens, Wat.Res., 36, 1135-1142 (2002)

14) Furukawa K., Lieu P.K., Tokitoh h., and Fujii T.: Development of single-stage nitrogen removal using anammox and partial nitritation (SNAP) and its treatment performances. Wat. Sci. Tech., 53 (6), 83-90 (2006)

15) APHA, AWWA and WEF: Standard methods for the examination of water and wastewater, 19th ed., American Public Health Association, Washington, D.C., USA (1995)

16) Kanda J.: Determination of ammonium in seawater based on the indophenol reaction with o-phenylphenol (OPP), Wat. Res., 29, 2746-2750 (1995)

17) Lowry O.H., Rosebrough N.J., Farr A.L., and Randall R. J.: Protein measurement with the folin phenol reagent. Journal of Biological Chemistry 193, 265-275 (1951)

18) Dubois M., Gilles K.A., Hamilton J.K., Rebers P.A., and Smith F.: Colorimetric method for determination of sugars and related substances. Analytical Chemistry 28 (3), 350-356 (1956)

19) Experimental Guidelines for Biotechnology: Society of Fermentation and Bioengineering, Osaka, Japan 98-99 (in Japanese) (1992)

20) Muyzer, G., and K. Smalla.: Application of denaturing gradient gel electrophoresis (DGGE) and temperature gradient gel electrophoresis (TGGE) in microbial ecology. Antonie Leeuwenhoek, 73, 127141 (1998)
21) Wingender J., Neu T.R., Flemming H-C.,; What are bacterial extracellular polymeric substances? In: Wingender J., Neu T.R., Flemming H-C., editors. Microbial extracellular polymeric substances: characterization, structure and function. Berlin: Springer (1999)

22) Costerto J.W., Irvin R.T., and Cheng K-J.: The bacterials glycocalyx in nature and disease, Ann. Rev. Microbiol, 35, 299-324 (1981)

23) Nielsen P.H., Jahn A., and Palmgren R.: Conceptual model for production and composition of exopolymers in biofilms, Water Sci. Technol., 36, 11-19 (1997)

24) Dignac M-F, Urbain V., Rybacki D., Bruchet A., Snidaro D., and Scribe P.: Chemical description of extracellular polymers: implication on activated sludge floc structure, Water Sci. Technol., 38, 45-53 (1998)

25) Laspidou C.S. and Rittmann B.E.: A unified theory for extracellular polymetic substances, soluble microbial products, and active and inert biomass, Wat. Res., 36, 2711-2720 (2002)

26) Hoffman M. and Decho A.W.: Extracellular enzymes within microbial biofilms and the role of the extracellular polymer matrix. In: Wingender J., Neu T.R., Flemming $\mathrm{H}-\mathrm{C}$., editors. Microbial extracellular polymeric substances: characterization, structure and function. Berlin: Springer (1999)

27) Fujii, T., H. Sugino, J. D. Rouse, and Furukawa K.: Characterization of the microbial community in an anaerobic ammonium-oxidizing biofilm cultured on a nonwoven biomass carrier. J. Biosci. Bioeng., 94, 412-418 (2002)

(Submitted 2007. 4. 18)

(Accepted 2008. 12. 29) 
